\title{
I.M. Bocheński and Theophrastus' Modal Logic
}

\author{
Luca Gili \\ (Université du Québec à Montréal)
}

Father Innocenty Maria Bocheński ${ }^{1}$ expounded his interpretation of Theophrastus' logic in three books: La logique de Théophraste (1947), Ancient Formal Logic (1951) and Formale Logik (1956). According to Bocheński, Theophrastus is a logician who developed and systematized Aristotle's late logical system and departed from his master only while discussing modal syllogistic. Bocheński's general assessment of Theophrastus presupposes a developmental interpretation of Aristotle's logic and a rephrasing of categorical syllogistic in the language of first-order predicate calculus, whereby the Aristotelian letters are interpreted as predicate letters of variables quantified over with the usual Fregean quantifiers. ${ }^{2}$ In the same years, Jan Łukasiewicz was interpreting Aristotle's logic in an analogous way. ${ }^{3}$ Our understanding of Aristotle's logic is now different from Bocheński's,

1 For the sake of consistency, I will be referring to the great Polish historian of logic by his religious name as a Dominican ("Innocenty") even though some of his writings were published under his baptismal name ("Józef”).

2 See, e.g., Bocheński's interpretation of prosleptic propositions in I.M. Bocheński, La logique de Théophraste, Fribourg 1947, p. 49 : “Théophraste enseignait aussi - toujours d'après Alexandre que les formules avec et sans quantificateur, cest-à-dire les formules

$\mathrm{C} \varphi \mathrm{x} \psi \mathrm{x}$

С Пх $\varphi x$ Пх $\psi \mathrm{x}$

sont équivalentes."

In the current logical notation, the two formulae are respectively: (i) $\varphi x \rightarrow \psi x$ and (ii) $\forall x$ $\varphi x \rightarrow \forall x \psi x$.

3 See especially J. Lukasiewicz, Aristotle's Syllogistic from the Standpoint of Modern Formal Logic, 2nd ed., Oxford 1957. Even though he has been accused by contemporary historians of logic of making historically inaccurate statements, Łukasiewicz was very careful in his wording. He 
and many scholars favour a "mereological" interpretation of Aristotle's syllogistic. ${ }^{4}$ This has an obvious implication for our assessment of Bocheński's overall interpretation of Theophrastus: if we choose a mereological interpretation of Aristotle's syllogistic, Theophrastus' "extensional" project becomes a radical novelty in the history of logic. ${ }^{5}$ But this characterization of the logic of the philosopher of Eresus is probably as inaccurate as the extensional reading of Aristotle. Leaving aside Bocheński's overall evaluation of Theophrastus' contributions to logic, we can still appreciate the ambitious programme of the Greek philosopher, if we pay attention to the minutiae of the reading offered by the Polish Dominican, even though La logique de Théophraste was published more than 70 years ago.

After Bocheński's groundbreaking works, there have been many publications on Theophrastus' logic. ${ }^{6}$ An incomplete list includes:

1) a collection of the logical fragments by Luciana Repici; ${ }^{7}$

maintained that Aristotle introduced "variables" by employing letters (cf. p. 7) but never claimed that Aristotle's letters are quantified over. On the contrary, Łukasiewicz wrote: "Aristotle had no clear idea of quantifiers and did not use them in his works; consequently we cannot introduce them into his syllogistic" (p. 83). However, he went on to say that "there are two points in his [sc. Aristotle's] system which we can understand better if we explain them by employing quantifiers" (pp. 83-84). For this reason, Łukasiewicz maintained that Aristotle's syllogistic applies only to non-empty terms (for a criticism of this latter claim, see S. Read, Aristotle and Łukasiewicz on Existential Import, "Journal of the American Philosophical Association" 2015, Vol. 1, No. 3, pp. 535-544). Bocheński maintains that Aristotle's analysis of universal propositions in Prior Analytics A, 41, 49b14-20 is similar to a Frege-style formalization: "Hier wird eine Analyse der Aussage 'A kommt jedem B zu' vorausgesetzt, die folgendermaßen gedeutet werden könnte: 'Für jedes x: wenn B dem x zukommt, dann kommt A dem x zu'; es würde sich dann um die modern formale Implikation handeln" (I.M. Bocheński, Formale Logik, Fribourg-München 1956, p. 92).

4 See especially M. Malink, Aristotle's Modal Syllogistic, Cambridge, MA 2013. Against Malink's interpretation, see J. Barnes, Truth, etc., Oxford 2007, pp. 386-419.

5 I have some reservations on this interpretation, as will be clear in what follows.

6 La logique de Théophraste includes an excellent survey of the sources for the reconstruction of Theophrastus' logic (cf. pp. 15-38). Bocheński was aware that a new collection of his logical fragments was a scholarly need: "La seule collection presque complete des fragments de la logique de Théophraste se trouve dans Prantl. Fr. Wimmer, Theophrasti Eresii Opera quae supersunt omnia, $t$. III, fragmenta continens, Lipsiae 1872 ne donne qu'une très petite partie de l'ensemble: tandis que Prantl cite plus de 100 fragments logiques, Wimmer nen a que 16. Prantl attribue souvent à Théophraste des textes manifestement stoïciens. Une collection nouvelle serait désirable" (p. 15, n. 19; "Prantl" obviously refers to C. Prantl, Geschichte der Logik im Abendlande, Leipzig 1927).

7 L. Repici, La logica di Teofrasto. Studio critico e raccolta dei frammenti e delle testimonianze, Bologna 1977. Fortenbaugh's collection of fragments (see next footnote) does not entirely supersede Repici's collection (cf. on this L. Gili, La sillogistica di Alessandro di Afrodisia. Sillogistica categorica e sillogistica modale nel commento agli Analitici Primi di Aristotele, Hildesheim 2011, p. 35). 
2) a complete collection of all extant fragments of Theophrastus' oeuvre by William W. Fortenbaugh and other scholars; ${ }^{8}$

3) a series of seminal studies by Mario Mignucci on Theophrastus' logic; ${ }^{9}$

4) Pamela Huby's commentary on fragments 68-136 Fortenbaugh (on logic). ${ }^{10}$ As Katerina Ierodiakonou makes clear in her recent entry on Theophrastus for the Stanford Encyclopedia of Philosophy, ${ }^{11}$ these studies have largely changed our understanding of Theophrastus' logic since the publication of La logique de Théophraste in 1947. But Bocheński's contributions can still open new paths to the historical research on Theophrastus' logic precisely because our understanding of Aristotle's modal syllogistic has also changed in recent years. In what follows, I will argue that Bocheński's reading presents Theophrastus as a much more revolutionary logician than the Polish Dominican was able to acknowledge. I will focus in particular on Theophrastus' modal logic, and I will show that Theophrastus laid the foundations for a different syllogistic: in my opinion, he did not abandon the "mereological approach" altogether (pace Bocheński's extensional reading), but proposed a logic that is conceived as a deductive system where the deducibility of an argument rests merely on the syntax of the language, whereas the Aristotelian validity seems to involve also semantic considerations, as is clear in the case of the proof of validity of the syllogistic mood Barbara $L X-L$. Such a system is not primarily designed as a theory of deduction for any of the Aristotelian sciences. Owing to this proposal, Theophrastus was probably one

$8 \quad$ W.W. Fortenbaugh et al., eds., Theophrastus of Eresus: Sources for His Life, Writings, Thought and Influence, 2 vols., Leiden 1992.

9 M. Mignucci, Per una nuova interpretazione della logica modale di Teofrasto, "Vichiana" 1965, Vol. 2, pp. 3-53; M. Mignucci, Theophrastus' Logic, in: Theophrastus: Reappraising the Sources, eds. J. van Ophuijsen, M. van Raalte, Leiden 1998, pp. 39-65.

10 P. Huby, Theophrastus of Eresus: Sources for His Life, Writings, Thought and Influence. Commentary Volume 2. Logic, with contributions on the Arabic material by D. Gutas, Leiden 2007.

11 Cf. K. Ierodiakonou, Theophrastus, in: The Stanford Encyclopedia of Philosophy, ed. E. Zalta, URL: https://plato.stanford.edu/entries/theophrastus (substantive revision published on 24.09.2020): "There has been a scholarly debate about whether Theophrastus recognized arguments in modus ponens, modus tollens, modus ponendo tollens and modus tollendo ponens:

If $p$, then $q$; but $p$; therefore $q$.

If $p$, then $q$; but not- $q$; therefore not- $p$.

Either $p$ or $q$; but $p$; therefore not- $q$.

Either $p$ or $q$; but not- $q$; therefore $p$.

While earlier commentators doubted that Theophrastus ever considered anything of the sort (see Bocheński 1947), recent scholars have maintained that he studied such arguments, or at least that he studied arguments which can be regarded as their forerunners." 
of the main sources of inspiration for the 1st-century BC Aristotelian Boethus of Sidon. ${ }^{12}$ Bocheński's adoption of the language of first-order logic to formalize Theophrastus' claims might now be called into question, but thanks to this "oldfashioned" methodology we can better appreciate the originality of the contribution of the philosopher of Eresus to the historical development of syllogistic.

\section{Bocheński on Theophrastus' Overall Contribution to Logic}

Bocheński's interest in Theophrastus' logic goes back to the 1930s ${ }^{13}$ In 1937, he published an article on Aristotle's and Theophrastus' understanding of modal propositions. ${ }^{14}$ In 1939, he was about to publish a monograph in French on Theophrastus' logic in the series Collectanea Logica edited by Łukasiewicz (vol. 1, pp. 195-304, with the title La logique de Théophraste). The typescript and the print version were both destroyed during the German bombing of Warsaw in September 1939. The only surviving copy sent to Heinrich Scholz was later destroyed during the Allied bombing of Münster in 1943. In 1944 Bocheński found in Rome incomplete proofs of his book and started working on it again. La logique de Théophraste would finally appear in 1947 (Librairie de l'Université, Fribourg en Suisse). ${ }^{15}$ Bocheński wrote again on Theophrastus in 1951 in Ancient Formal Logic and in 1956 in his famous Formale Logik. In these two latter books, Father Bocheński devoted only a few pages to Theophrastus, but these sketchy remarks are useful to reconstruct what he maintained to be the core contribution to logic of the philosopher of Eresus. In his 1951 book, Bocheński wrote:

In the light of the preserved fragments, we see that the work of Theophrastus consisted mainly in the development of the doctrines of Aristotle in the manner of Aristotle's own late writings. By doing so, Theophrastus contributed considerably to the formation of what was later called "classical logic" and

12 I argued in favour of this claim in L. Gili, Boeto di Sidone e Alessandro di Afrodisia intorno alla sillogistica aristotelica, "Rheinisches Museum für Philologie" 2011, Vol. 154, pp. 375-397.

13 On Bocheński's scholarly activity in Rome at the Pontifical University of St. Thomas Aquinas (the "Angelicum"), see E. Kaczyński, La ricerca logica di I.M. Bocheński durante il suo insegnamento all' "Angelicum" (1934-1939), "Angelicum" 2003, Vol. 80, No. 1, pp. 9-33.

14 I.M. Bocheński, Notes historiques sur les propositions modales, "Revue des sciences philosophiques et théologiques" 1937, Vol. 26, No. 4, pp. 673-692.

15 I take this information from I.M. Bocheński, La logique de Théophraste, op. cit., pp. 5-6. 
perhaps also opened the path to the Stoic-Megaric Logic. At the same time, however, it must be stressed that his teaching contains several un-Aristotelian elements, especially in modal logic. ${ }^{16}$

In the short notes of the Formale Logik, the Polish Dominican makes analogous claims. ${ }^{17}$ With the expression "classical logic," Bocheński does not refer to first-order predicate calculus, but to the traditional "Aristotelian logic" that was taught across Europe since the discovery of the logica nova. According to Bocheński, Theophrastus followed in the footsteps of his master and systematized his system, thereby making it suitable for handbook expositions. Theophrastus developed new ideas only in modal logic. Bocheński argues in detail for this interpretation in his 1947 book as well. At this level of generality, one could hardly say that Bocheński's picture needs any revision. It is worth noting, however, that the Polish Dominican took for granted that both Aristotle's and Theophrastus' treatment of quantified propositions could be translated into the language of lower predicate calculus, where a sentence like "All Dominicans pray the rosary" becomes a material implication of this form:

(1) $\forall x(A x \rightarrow B x)$ (where the predicate letters " $A$ " and " $\mathrm{B}$ " stand respectively for "Dominican" and "is praying the rosary").

Far from being a mere logical tool to analyze the sentences, the formalization in the language of first-order logic had profound philosophical implications. In Bocheński's view, both Aristotle and Theophrastus were working with a paradigm where individual variables are quantified over, predicate letters are not, and universal affirmative propositions involve a material implication. Aristotle and Theophrastus were obviously not aware of the doctrine of quantification, but they worked with this scheme in mind. Bocheński saw a deep philosophical reason for this reading:

It is worth noting that after Plato the logical analysis of propositions reaches

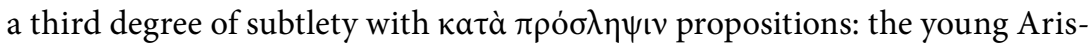

16 I.M. Bocheński, Ancient Formal Logic, Dordrecht 1951, p. 72.

17 Cf. I.M. Bocheński, Formale Logik, op. cit., p. 114: "Er [sc. Theophrastus] hat, erstens, verschiedene Lehren seines Meisters so entwickelt, daß er sozusagen die spätere 'klassische' Logik vorbereit hat; der aristotelischen modalen Syllogistik hat er, zweitens, seine eigene ganz andere gegenübergestellt; endlich entwarf er eine Lehre vom hypothetischen Syllogismus, welche die megarisch-stoische Lehre vorbereitete." 
totle identifies only two elements, i.e. the subject and the predicate (the copula does not play any significant role); in the Analytics, the copula is already one of the three necessary elements of the proposition; finally, in our author [sc. Theophrastus], we find four elements: two terms, that correspond to the subject and the predicate, an undetermined substrate and the [material] implication that replaces the copula. [...] We should add an extra-logical remark about the

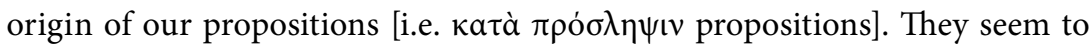
fit Aristotle's metaphysics, because we know that Aristotle was distinguishing two elements in every empirical object, i.e. an undetermined substrate or matter and a form that determines this substrate. Our propositions seem to be a transposition of this doctrine in the logical space, because they also divide the subject and the predicate into two elements, i.e. an undetermined $x$, i.e. the substrate, and its determination. ${ }^{18}$

I am inclined to argue that Bocheński was not able to appreciate in full the philosophical meaning of Theophrastus' contribution to logic precisely because of the mistaken assumption according to which predicate letters and variables

18 I.M. Bocheński, La logique de Théophraste, op. cit., pp. 50-51 : "Il est intéressant de constater

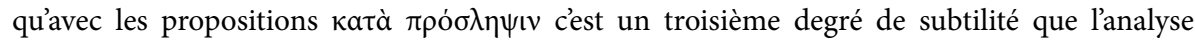
logique de la proposition atteint depuis Platon : chez le jeune Aristote, on y distingue deux éléments seulement, un sujet et un prédicat - la copule ne joue aucun rôle important ; dans les Analytiques, elle est déjà un des trois facteurs nécessaires de la proposition ; enfin chez notre auteur [sc. chez Théophraste] nous en trouvons quatre : deux termes, qui tiennent la place du sujet et du prédicat, le substrat indéterminé et l'implication substituée à la copule. [...] Une remarque extralogique s'impose quant à l'origine de nos propositions. Elles semblent notamment bien correspondre à la métaphysique aristotélicienne : on sait, en effet, qu'Aristote distinguait en tout objet empirique deux éléments, un substrat indéterminé, la matière, et une forme qui détermine ce substrat. Nos propositions semblent une transposition de cette doctrine dans l'ordre logique, car elles divisent aussi le sujet et le prédicat en deux éléments, un $\mathrm{x}$ indéterminé qui est substrat et une détermination" (my translation). Prosleptic propositions are propositions where a third term is (implicitly) introduced. The prosleptic counterpart of " $B$ is said of all $A$ " is " $B$ is said of all of which $A$ is said" or "For every $X$, if $A$ is said of all $X$, then $B$ is said of all X." Aristotle introduced prosleptic propositions in Pr. An. B, 5, 58a29-30, but did not

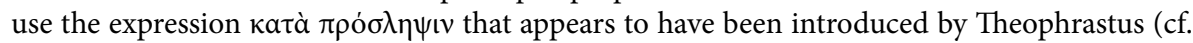
Alex. Aphr. In An. pr. 378.14; for an overview of the ancient sources on prosleptic propositions and prosleptic syllogisms, cf. W. Kneale, M. Kneale, Prosleptic Propositions and Arguments, in: Islamic Philosophy and the Classical Tradition: Essays Presented by His Friends and Pupils to Richard Walzer on His Seventieth Birthday, eds. S.M. Stern, A. Hourani, V. Brown, Columbia, SC 1972, pp. 189-207). According to Malink, Aristotle might have been aware of this classification (cf. M. Malink, Figures of Prosleptic Syllogisms in Prior Analytics 2.7, "Classical Quarterly" 2012, Vol. 62, No. 1, pp. 163-178). 
belong to different semantic types. I think that neither Aristotle nor Theophrastus would have accepted a reading of quantified propositions where

$\mathrm{x}$ is a zero-order individual variable, and $\mathrm{A}$ and $\mathrm{B}$ are first-order predicates.

In the standard first-order models, the semantic value of zero-order terms is an individual, and the semantic value of first-order predicates is a set of individuals. ${ }^{19}$

Both Aristotle and Theophrastus had a mereological understanding of letters in their syllogistic, as Marko Malink has argued at length in his publications. ${ }^{20}$ According to this reading, all the letters appearing in the dictum de omni et de nullo stand for parts and not for individuals. Since the validity of syllogisms rests on the dictum de omni et de nullo, we could not say that the semantic value of a zero-order term in any premise or conclusion of a valid mood is an individual, while the semantic value of a first-order predicate is a part. But Bocheński was right about a crucial point: there is a historical direction towards a type of logic that is freer from its purpose of serving as the deductive system of a particular science. A logic that is not designed for an Aristotelian science could eventually be treating individual variables as belonging to a lower semantic type than predicate letters. Pace Bocheński, Theophrastus did not make this last step, but certainly laid the foundations for this possible outcome in the historical development of logic. Interestingly, Theophrastus was in all likelihood the main source of inspiration for Boethus of Sidon, who might have been thinking of prosleptic propositions when he argued contra Aristotelem that the syllogisms in the three figures are all complete. ${ }^{21}$ Boethus still advances a heterodox reading of the dictum de omni et de nullo, that is, a reading whereby all letters and variables have the same semantic value (a universal), but his philosophy seems to be in need of quantifiers for individuals. ${ }^{22}$

19 M. Malink, A Non-Extensional Notion of Conversion in the Organon, "Oxford Studies in Ancient Philosophy" 2009, Vol. 37, p. 110.

20 See again M. Malink, Aristotle's Modal Syllogistic, op. cit.

21 I take the liberty to refer again to L. Gili, Boeto di Sidone e Alessandro di Afrodisia, op. cit.

22 Marwan Rashed makes this claim in his paper on Boethus' syllogistic (pp. 255-289) in R. Chiaradonna, M. Rashed, Boéthos de Sidon - Exégète d'Aristote et philosophe, Commentaria in Aristotelem Graeca et Byzantina - Series Academica 1, Berlin-Boston, MA 2020: "(dictum

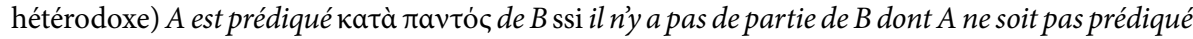
Boéthos, qui affirme, dans son ontologie, la préséance de l'individu sur ses déterminations formelles, semblerait n’avoir aucune raison de privilégier une lecture de ce type" (p. 283). 
If we re-read Bocheński's book with these historical insights in mind, we cannot but appreciate how the Polish Dominican anticipated many of these conclusions in his reconstruction of Theophrastus' modal logic.

\section{Bocheński on Theophrastus' Modal Logic}

Even though I am not suggesting that Theophrastus endorsed an extensional reading of propositions, there are certainly hints that the philosopher of Eresus might have been open to a logic that is free from its function to serve as the underlying deductive system of one of the Aristotelian sciences. In so doing, Theophrastus was probably not looking at the predicative relations between subjects and predicates as the grounds for the modality of a premise or a conclusion, but was offering a mere syntactic characterization of modalities. This is not tantamount to stating that Theophrastus abandoned the mereological approach of his master, but he certainly did abandon the rationale for a mereological approach, that is, the idea that premises and conclusions always express a predicative relation between two praedicabilia. The praedicabilia always denote concepts, that is, classes. If all the terms appearing in a syllogism are predicables, they all refer to classes, not to individuals.

There are also hints that Theophrastus might have favoured a merely extensional reading of propositions. The best example is Theophrastus' proof for the validity of the law of conversion for universal negative propositions. Aristotle had to introduce ecthesis to prove this law - a procedure that is certainly problematic for readers who translate Aristotle's sentences into the language of first-order predicate calculus. ${ }^{23}$ Theophrastus claimed to have a simpler proof for the conver-

23 Simply put, either Aristotle has to use the law of conversion for particular affirmative propositions to demonstrate by ecthesis the law of conversion of universal negative propositions (but this would be a circular reasoning, inasmuch as the law for particular affirmative propositions is demonstrated by means of the law of conversion for universal negative propositions) or he has to use extralogical notions (cf., e.g., J. Łukasiewicz, Aristotle’s Syllogistic, op. cit., p. 60: “[A] proof by perception is not a logical proof"). Łukasiewicz and Bocheński take the ecthetic conversion of particular affirmative propositions to be self-evident, thereby adopting a strategy similar to the one of Theophrastus (who took as self-evident the law of conversion for universal negative propositions): "Chez Aristote, la preuve est 'ecthétique' et peut être résumée ainsi: La thèse à prouver est 'EYbaYab', suppose qu'elle soit fausse, 'Yba' implique 'NYba'; or, ceci implique à son tour qu'il existe (au moins) un $c$ tel, qu'il est à la fois un (élément de la classe) $a$ et un (élément 
sion of universal negative propositions. ${ }^{24}$ Bocheński does not develop any extensional reading of this proof probably because that was rather obvious within the framework of his reading of Theophrastus. But it is certainly worth noting that, for Theophrastus, "No $A$ is $B$ " means that $A$ and $B$ are "separated" - and one can hardly avoid thinking of non-overlapping diagrams representing the extensions of $A$ and $B$. It is still possible that the diagrams would have included the "parts" of the notions $A$ and $B$, but I daresay that we are more naturally inclined to think that they would have represented classes of individuals.

In this case, Bocheński's extensional reading, although controversial, is certainly enlightening. The picture becomes more complex if we look at modal syllogistic. In his chapter on Theophrastus' modal logic (pp. 67-102), Bocheński begins by summarizing Aristotle's modal theses. In Bocheński's reconstruction, Theophrastus introduced two novelties in his system: ${ }^{25}$

1) he replaced two-sided possibility with one-sided possibility;

2) he introduced the "peiorem rule" (peiorem semper sequitur conclusio partem) in virtue of which moods such as Barbara $L X-L$ are taken to be invalid, pace Aristotle, Prior Analytics A, 9 (where such moods are taken to be valid). Barbara $L X-L$ is a mood where the major premise is a necessary universal affirmative proposition, the minor premise is a categorical uni-

de la classe) $b$; et s'il en est ainsi, il n'est pas vrai qu'aucun $b$ n'est $a$ " (I.M. Bocheński, La logique de Théophraste, op. cit., p. 55; cf. also J. Łukasiewicz, Aristotle's Syllogistic, op. cit., p. 61).

Both Alexander and Philoponus present this proof by Theophrastus (cf. I.M. Bocheński, La logique de Théophraste, op. cit., p. 54, n. 201). For a comparative analysis of these two sources I take the liberty to refer the reader to L. Gili, Il confronto di Giovanni Filopono con Alessandro di Afrodisia intorno al problema della conversione delle proposizioni, "Elenchos. Rivista di studi sul pensiero antico" 2015, Vol. 36, No. 2, pp. 317-339.

25 Cf. I.M. Bocheński, La logique de Théophraste, op. cit., p. 95 : "Nous avons noté les différences suivantes entre le système de la modalité de Théophraste et celui d'Aristote :

(a) Tandis que chez Aristote ' $M p$ ' est défini par léquivalence 'EMpKNSpNSNp', chez Théophraste il y a presque partout le sens déterminé par la formule 'EMpNSN $p$ '.

(b) Tandis qu'Aristote admet des modes syllogistiques dans lesquels la conclusion est 'plus forte' qu'une des prémisses (par exemple 'CKSpZqSp'), chez Théophraste la règle du peiorem est rigoureusement appliquée à tous les modes.

(c) La conséquence de (b) et surtout de (a) est que le système de Théophraste est beaucoup plus homogène que celui d'Aristote et contient presque exclusivement des thèses analogues à celles de la logique assertorique; Aristote a, par contre, dans sa logique de la modalité beaucoup de thèses qui nont pas d'analogues assertoriques et beaucoup de thèses assertoriques sans analogues dans certains groupes de thèses de la logique de la modalité" (Bocheński's formula "CKSpZqSp" in (b) might be a lapsus calami for "CKSpZqSr," if the Polish Dominican intended to refer to a Barbara $L X-L$ mood). 
versal affirmative proposition, and the conclusion is a necessary universal affirmative proposition. This mood is a valid syllogism for Aristotle, but not according to Theophrastus, who maintained that the conclusion must always have the weaker property, which can be found in any of the premises: if one of the premises is negative, the conclusion will also be negative; if one of the premises is particular, the conclusion will be particular; if one of the premises is not necessary, the conclusion will not be necessary.

According to Bocheński, Aristotle conceives of the possibility operator as onesided possibility chiefly in his De interpretatione, whereas in the Prior Analytics he mostly uses two-sided possibility. ${ }^{26}$ If Theophrastus worked on Aristotle's last logical system, we could conclude that the composition of the Prior Analytics precedes that of the treatise De interpretatione. ${ }^{27}$ This historical claim presupposes the questionable idea that (a) Aristotle employs two-sided possibility in the Prior Analytics and one-sided possibility in De interpretatione, and (b) that Theophrastus wanted to develop the last system proposed by Aristotle. But Bocheński was right in stressing that the philosopher of Eresus does not seem to use two-sided possibility in his modal syllogistic.

A few years before the publication of La logique de Théophraste, Albrecht Becker published a landmark contribution to the study of Aristotle's modal syllogistic, Die aristotelische Theorie der Möglichkeitsschlüsse. ${ }^{28}$ In that book, ${ }^{29}$ Becker maintained that Aristotle's Barbara $L X-L$ mood is valid because the necessity operator is read de re, whereas Theophrastus takes the same mood to be invalid because for him

26 Let " $M_{1}$ " be the operator for one-sided possibility and " $M_{2}$ " the operator for two-sided possibility. It is possible to define the two operators as follows:

$M_{1} p \equiv \nabla p$

$M_{2} p \equiv \diamond p \wedge \diamond \neg p$

On two-sided and one-sided possibilities in De interpretatione, see M. Malink, Aristotle on One-Sided Possibility, in: Logical Modalities from Aristotle to Carnap: The Story of Necessity, eds. M. Cresswell, E. Mares, A. Rini, Cambridge 2016, pp. 29-49.

27 Cf. I.M. Bocheński, La logique de Théophraste, op. cit., p. 102: "On sait que Théophraste suit Aristote dernière manière. Sa logique de la modalité serait donc un argument pour placer le Per 13 [sc. De interpretatione 13] après les APr."

28 A. Becker, Die aristotelische Theorie der Möglichkeitsschlüsse. Eine logisch-philologische Untersuchung der Kapitel 13-22 von Aristoteles' Analytica Priora I, Berlin 1933.

29 On Becker's interpretation of Aristotle's modal syllogistic, see L. Gili, Interpreting Aristotle's Modal Syllogistic, "Documenti e studi sulla tradizione filosofica medievale" 2015, Vol. 26, pp. 1-12, and L. Gili, La sillogistica del necessario in alcune interpretazioni novecentesche, "Rivista di filosofia neoscolastica" 2016, Vol. 2, pp. 445-463. 
the necessity operator should be interpreted de dicto. The laws of conversions for modal propositions, however, are valid only under a de dicto reading of the operators, and Aristotle's modal syllogistic turns out to be inconsistent in Becker's interpretation. Bocheński was not satisfied with the conclusions of Becker's book. According to the Polish Dominican, a Barbara $L X-L$ mood is "intuitively correct" - its validity does not hinge on a de re reading of the necessity operator. The modal operators are rather defined on the basis of their use in the context of valid syllogisms ${ }^{30}$ Prima facie, Bocheński's analysis may seem superficial, but it perfectly fits Malink's suggestion that the minor premise of a Barbara $L X-L$ expresses an essential predication, inasmuch as the middle term should either be a definition or a genus or a species. Within this framework, Aristotle's enterprise appears to be consistent and Bocheński is right in stressing that it is only by chance that the validity of Barbara $L X-L$ can also be demonstrated if we assume that the necessity operator is de re in both the major premise and the conclusion.

Aristotle was guided by the idea that modal propositions express the predicative relationships between praedicabilia presumably because he conceived of his modal logic as the underlying deductive system of his theoretical sciences, such as his physics. ${ }^{31}$ Bocheński is right in stressing that Theophrastus' system is original and aims at simplicity. ${ }^{32}$ In the light of recent contributions on Aristotle, ${ }^{33}$ we could hypothesize (a) that Theophrastus no longer grounded his modalities on the different types of predication generated by the combination of the praedicabilia. And if this were proven to be the case, one could further argue (b) that Theophrastus wanted to develop a modal system independently of its use in the context of one of the Aristotelian sciences. Future research will have to assess

30 Cf. I.M. Bocheński, La logique de Théophraste, op. cit., pp. 97-98: “Aristote n’aurait pas pensé à une structure déterminée des propositions modales, si non dans quelques passages ajoutées plus tard. Ses thèses sont basées sur une certaine intuition de la possibilité et du syllogisme; il suffit d'y penser un peu et l'on voit immédiatement que A 5-7 aussi bien, par exemple, que le mode 'CKSUmaZUbmSUba' [i.e. Barbara $L X-L$ ] paraissent intuitivement correct. C'est par hasard que certaines de ces thèses se déduisent parfaitement de l'hypothèse beckérienne."

31 Mauro Mariani argued for this claim in Logica modale e metafisica. Saggi aristotelici, Pisa 2018, pp. 61-84 ("Semantica aristotelica e sillogistica modale") and pp. 193-215 ("Sillogistica modale e teorie della predicazione").

32 Cf. I.M. Bocheński, La logique de Théophraste, op. cit., p. 94 : "En somme, la syllogistique modale de Théophraste devait être, quant aux thèses, remarquablement plus simple que celle d'Aristote."

33 I refer mostly to Malink's and Mariani's books (cited respectively in footnotes 4 and 31). For additional references, see L. Gili, Interpreting Aristotle's Modal Syllogistic, op. cit. 
each of these two claims, but it is worth noting that Bocheński's interpretation undoubtedly provokes these reflections and these working hypotheses.

In conclusion, Theophrastus developed a new modal syllogistic, probably because he had a different understanding of the possibility operator and of syllogistic validity. ${ }^{34}$ While Aristotle uses both one-sided and two-sided possibility, Bocheński argues that Theophrastus chooses to employ only one-sided possibility. While addressing syllogistic validity, Bocheński writes that

in Aristotle's system, the middle term (in the first figure) is qualified by the major term and the minor term is conceived of as an element of the class represented by the middle term, whereas in Theophrastus' system, the three terms are looked at as extensions that are united or "separated" among each other; this union or separation may be either common, necessary or possible. ${ }^{35}$

According to Bocheński, the letters represent the extensions of classes in both Aristotle and Theophrastus. In Aristotle's system, however, the major term is supposed to "qualify" the middle term in the first figure - and this suggests that Aristotle had in mind the real-world application of logic as a tool for capturing real relations. In Theophrastus, on the other hand, this guiding idea appears to be absent: the philosopher of Eresus is merely interested in the relations between the classes represented by the letters.

\section{Conclusion}

The extensional reading of Theophrastus' logic is the most natural outcome for a historian of logic who happened to be writing in the 1930s and 40s, when firstorder logic was taken to be the logic and any argument had to be formalized in the language of the only logic available. Bocheński did not only employ the lan-

34 Cf. I.M. Bocheński, La logique de Théophraste, op. cit., p. 98: “Théophraste, en changeant beaucoup de choses dans la logique de la modalité aristotélicienne, sest probablement laissé guider non pas par une idée de la structure différente, mais par une autre intuition de la possibilité et du syllogisme."

35 I.M. Bocheński, La logique de Théophraste, op. cit., p. 100: "[T]andis que chez Aristote le terme moyen se trouvait (en $1^{\text {re }}$ figure) qualifié du terme majeur et le terme mineur était conçu comme un élément de la classe représentée par le terme moyen - chez Théophraste les trois termes sont considérés en extension, unis ou 'séparés' entre eux; cette union ou séparation peut être commune, nécessaire ou possible" (my translation). 
guage of the lower predicate calculus as a tool to formalize Theophrastus' theses, but maintained that the philosopher of Eresus had an extensional understanding of the relations expounded by the propositions occurring in a syllogism. In the light of more recent studies on Aristotle's modal logic, we might be wary of this conclusion. But thanks to his outdated methodology, Bocheński was able to show an undeniable tendency in Theophrastus' oeuvre, that is, the attempt at creating a logical system where syllogistic validity was no longer grounded on the theory of predication. In making this claim, Bocheński was definitely on the right track.

In future studies, scholars will have to establish whether Theophrastus maintained that the three terms that figure in a prosleptic proposition belong to the same semantic type or to different semantic types (as Bocheński believed). But even if Theophrastus followed his master in offering a mereological foundation for syllogistic, as I believe to be the case, there is a striking difference in the approaches of the two philosophers. As Bocheński rightly observed, Aristotle's remarks on the validity of Barbara $L X-L$ are intuitively correct, but if we want to make sense of this intuition, we must admit that all the letters that appear in a syllogistic premise and in its prosleptic counterpart belong to the same semantic type and are one of the predicables expounded in the Topics. Accordingly, the major premise of Barbara $L X-L$ is necessary because it expresses an essential predication or the predication of a proprium. If this is the case, the middle term can only be a definition, or a genus, or a difference, or a proprium, but such a term can only appear in an essential predication or in the predication of a proprium under the hypothesis that a syllogistic premise only deals with per se predications. ${ }^{36}$ Aristotle can state the validity of Barbara $L X-L$ only on the basis of these semantic considerations. As Bocheński remarked, Theophrastus has a simpler system, where a mood is valid only insofar as it is deductible from the basic

36 It is obviously conceivable to form a syllogism where the minor premise expresses an accidental predication:

(a) Able to laugh is necessarily said of all human beings.

(b) Walking is said of all those who are able to laugh.

Therefore, (c) walking is (necessarily?) said of all human beings.

In this example, the major premise is necessary because it expresses the predication of a proprium. The minor premise, however, does not express a per se predication, but rather an accidental predication, whereby $A$ is said of $B$, because there is a $C$ to which both $A$ and $B$ happen to belong. In this case, one can hardly see how it would be possible to infer a necessary conclusion. Hence, it seems reasonable to stipulate that Aristotle would only consider per se predications in his syllogistic. 
rules of the system, regardless of any semantic consideration about the types of predication that are expressed in the syllogistic premises and conclusions. The extensional reading proposed by the Polish Dominican helps us understand this simplicity. Furthermore, an extensional reading is at odds with the goal of syllogistic to serve as the underlying deductive theory of an Aristotelian science because Aristotelian sciences are not about individuals, but about genera and species. Did Theophrastus want to develop a logic for its own sake, regardless of its use in a scientific context? I have hinted in this paper that I think this was the case. If this claim were to be demonstrated in future studies on Theophrastus' logic, Bocheński will have to be credited for pointing us in the right direction. ${ }^{37}$

\section{Acknowledgements}

I thank Mauro Mariani, Lorenz Demey and the two anonymous reviewers of the journal for their comments on this paper. Any remaining mistakes are only mine.

\section{Bibliography}

Barnes J., Truth, etc., Oxford 2007.

Becker A., Die aristotelische Theorie der Möglichkeitsschlüsse. Eine logisch-philologische Untersuchung der Kapitel 13-22 von Aristoteles' Analytica Priora I, Berlin 1933.

Bocheński I.M., Ancient Formal Logic, Dordrecht 1951.

Bocheński I.M., Formale Logik, Fribourg-München 1956.

Bocheński I.M., La logique de Théophraste, Fribourg 1947.

Bocheński I.M., Notes historiques sur les propositions modales, "Revue des sciences philosophiques et théologiques" 1937, Vol. 26, No. 4, pp. 673-692.

Chiaradonna R., Rashed M., Boéthos de Sidon - Exégète d'Aristote et philosophe, Commentaria in Aristotelem Graeca et Byzantina - Series Academica 1, Berlin-Boston, MA 2020.

Fortenbaugh W.W., Huby P.M., Sharples R.W., Gutas D., eds., Theophrastus of Eresus: Sources for His Life, Writings, Thought and Influence, 2 vols., Leiden 1992.

$37 \quad$ It could be objected that any extensional reading of Theophrastus' logical fragments would have brought about the same result, but Bocheński has the historical merit of having been the first scholar who consistently applied this method in order to interpret the texts of the philosopher of Eresus. 
Gili L., Boeto di Sidone e Alessandro di Afrodisia intorno alla sillogistica aristotelica, "Rheinisches Museum für Philologie" 2011, Vol. 154, pp. 375-397.

Gili L., Il confronto di Giovanni Filopono con Alessandro di Afrodisia intorno al problema della conversione delle proposizioni, "Elenchos. Rivista di studi sul pensiero antico" 2015, Vol. 36, No. 2, pp. 317-339.

Gili L., Interpreting Aristotle's Modal Syllogistic, "Documenti e studi sulla tradizione filosofica medievale" 2015, Vol. 26, pp. 1-12.

Gili L., La sillogistica del necessario in alcune interpretazioni novecentesche, "Rivista di filosofia neoscolastica" 2016, Vol. 2, pp. 445-463.

Gili L., La sillogistica di Alessandro di Afrodisia. Sillogistica categorica e sillogistica modale nel commento agli Analitici Primi di Aristotele, Hildesheim 2011.

Huby P., Theophrastus of Eresus: Sources for His Life, Writings, Thought and Influence. Commentary Volume 2. Logic, with contributions on the Arabic material by D. Gutas, Leiden 2007.

Ierodiakonou K., Theophrastus, in: The Stanford Encyclopedia of Philosophy, ed. E. Zalta, URL: https://plato.stanford.edu/entries/theophrastus (substantive revision published on 24.09.2020).

Kaczyński E., La ricerca logica di I.M. Bocheński durante il suo insegnamento all' "Angelicum" (1934-1939), "Angelicum" 2003, Vol. 80, No. 1, pp. 9-33.

Kneale W., Kneale M., Prosleptic Propositions and Arguments, in: Islamic Philosophy and the Classical Tradition: Essays Presented by His Friends and Pupils to Richard Walzer on His Seventieth Birthday, eds. S.M. Stern, A. Hourani, V. Brown, Columbia, SC 1972, pp. 189-207.

Łukasiewicz J., Aristotle's Syllogistic from the Standpoint of Modern Formal Logic, 2nd ed., Oxford 1957.

Malink M., Aristotle on One-Sided Possibility, in: Logical Modalities from Aristotle to Carnap: The Story of Necessity, eds. M. Cresswell, E. Mares, A. Rini, Cambridge 2016, pp. 29-49, https://doi.org/10.1017/CBO9781139939553.003.

Malink M., Aristotle's Modal Syllogistic, Cambridge, MA 2013, https://doi.org/ 10.4159/harvard.9780674726352.

Malink M., Figures of Prosleptic Syllogisms in Prior Analytics 2.7, "Classical Quarterly" 2012, Vol. 62, No. 1, pp. 163-178, https://doi.org/10.1017/ S0009838811000565.

Malink M., A Non-Extensional Notion of Conversion in the Organon, "Oxford Studies in Ancient Philosophy" 2009, Vol. 37, pp. 105-141.

Mariani M., Logica modale e metafisica. Saggi aristotelici, Pisa 2018. 
Mignucci M., Per una nuova interpretazione della logica modale di Teofrasto, "Vichiana" 1965, Vol. 2, pp. 3-53.

Mignucci M., Theophrastus' Logic, in: Theophrastus: Reappraising the Sources, eds. J. van Ophuijsen, M. van Raalte, Leiden 1998, pp. 39-65.

Prantl C., Geschichte der Logik im Abendlande, Leipzig 1927.

Read S., Aristotle and Łukasiewicz on Existential Import, "Journal of the American Philosophical Association” 2015, Vol. 1, No. 3, pp. 535-544, https://oi.org/ 10.1017/apa.2015.8.

Repici L., La logica di Teofrasto. Studio critico e raccolta dei frammenti e delle testimonianze, Bologna 1977.

\section{Summary}

Innocenty Maria Bocheński expounded his interpretation of Theophrastus' logic chiefly in his book La logique de Théophraste (1947). In Bocheński's reconstruction, Theophrastus worked on the last insights of Aristotle's syllogistic and systematized it, thereby opening the door to later (Stoic) developments in the history of logic. A closer look at Bocheński's interpretation of Theophrastus' logic can lead us to reassess the originality of the contribution of the philosopher of Eresus. As more recent studies have convincingly shown, Aristotle's modal system is grounded on the theory of predication expounded in the Topics. The validity of Barbara $L X-L$ rests on the essential predications that the major premise and the conclusion are descriptive. According to Bocheński, Theophrastus had an extensional understanding of logic, as is clear from his proof for the rules of conversion of categorical universal propositions. Bocheński also stresses that Theophrastus consistently avoids Aristotle's two-sided possibility and this might also be read as an attempt to develop a self-contained logical system that is not merely seen as the deductive system of a theoretical discipline. Bocheński's overall assessment of Theophrastus' logic might be in need of revision, inasmuch as our understanding of Aristotle's logical enterprise has radically changed in the last decades, but the minutiae of Bocheński's reading of Theophrastus are compelling and can stimulate new studies on the successor of the Stagirite.

Key words: I.M. Bocheński, Theophrastus, modal syllogistic, Prior Analytics, Aristotle, modal logic 